\title{
PRIVATIZATION PROGRAM FOR 2014-2016: FORMAL SHIFTS AND UNCERTAIN PROSPECTS
}

\author{
G.Malginov, A.Radygin
}

The outcome of the current privatization program, to be completed this year, will strongly depend on the general situation in the Russian economy, and in particular on the behavior of the domestic stock market. In the explanatory documents attached to the draft law on federal budget for 2016 submitted to parliament by the government, it is stated that the revenues from privatization are expected to amount to more than $R b 33.2 \mathrm{bn}$. This goal does not appear to be quite realistic, though. The planned sum of budget revenue to be generated by this source in 2016 is comparable to the total amount of revenue generated by the privatization program for 2011-2013 over the entire 3-year period of its implementation. However, the economic and political situation then was very different from what we have been experiencing over the last two years (massive capital outflow, the introduction of economic sanctions, the ruble's plummeting exchange rate, and the probability of protracted recession in the national economy).

The past year was the second year of the implementation of the Forecast Plan (Program) of Federal Property Privatization and the Main Directions of Federal Property Privatization for 2014-2016, approved by Directive of the RF Government of July 1, 2013, No 1111-r.

In 2015, the stakes (or shares in charter capital) in a total of 103 economic societies were actually sold (vs. 107 in 2014), while in respect of 35 federal state unitary enterprises (FSUE), the relevant decisions con $n$ cerning the terms of their privatization were finalized (vs. 33 in 2014). These results follow the overall trend of recent years: the number of sold stakes (or participatory shares) was constantly on the decline, while the privatization of unitary enterprises, if we consider the number of those of them that were subject to specially issued directives concerning the terms of their privatization, was basically progressing at the same pace as before. Against this background, a dramatic increase in the number of sold immovable property entities should be noted ( 38 vs. 11 in 2014).

In 2015, the distinctive features of the privatization process were as follows:

- no sales of shares in biggest companies, in respect of which the specific timeframe and method of privatization were to be determined by the RF Government with due regard to the market situation and to the recommendations of top investment consultants, took place that year;

- independent (non-governmental) sellers played a prominent role in closing the deals of sale of state-owned assets and generating privatization revenues (thus, Auction House of the Russian Federation (RAD OJSC) sold stakes to the value of $\mathrm{Rb} 5.3 \mathrm{bn}$, which amounts to more than $72 \%$ of the total proceeds of sales of state stakes, and is more than the aggregate privatization revenue received over the two previous years);

- significant expansion of the privatization program by means of adding nearly 1.2 immovable property entities; as a result, the entire structure of property earmarked for privatization was altered, as instead 
of separate stakes in the economic societies holding titles to property complexes, entire immovable property entities were privatized.

Former head of the RF Federal Agency for State Property Management (Rosimushchestvo) Olga Dergunova said, at the meeting of the Public Council under the RF Ministry of Economic Development in late March 2016, that the absence of large-scale privatization deals last year was the upshot of the government's deliberately chosen policy in view of the market's unpreparedness to substantial investment ${ }^{1}$. The only possible deal -the alienation of shares in Sovkomflot PJSC (Public Corporation) -was postponed due to the worsening macroeconomic situation and low investment activity on the domestic market, as well as the currently unfavorable situation in the tanker shipping market and the introduction of restrictive measures against big Russian companies.

Last year's biggest privatization deal was the sale of Murmansk Sea Fishing Port (the entire $100 \%$ stake) for $\mathrm{Rb} 1,027 \mathrm{bn}$. The other major privatization deals were the sales of state stakes in the Moscow-based company JSC Aviatechsnab (for Rb 986m); JSC Murmansk Shipping Company (25.5\%, to the value of $\mathrm{Rb} 660 \mathrm{~m}$ ); Fundamentproekt (Rb $454.8 \mathrm{~m}$ ) and E. I. Rytvin Scientific and Industrial Complex Supermetal (Rb 307m) (both in Moscow); Labinsky Poultry Breeding Farm (Krasnodar Krai, Rb 303.3m); and one of Moscow's Bread Baking Plants (Rb 216.4m).

Besides, we should note the comprehensive work that was underway following the decision concerning the strategic development of Moscow's airport system based on the principle of public-private partnership (PPP). In February 2016, agreements were signed by government representatives and private stakeholders concerning the consolidation of assets of Vnukovo and Sheremetyevo airports, whereby the State (as the holder of blocking stakes) retained the necessary control over their joint operation and the key decision-making function.

In order to improve the property sale system and cooperation with potential investors, Rosimushchestvo and its territorial agencies got involved in more active promotion and marketing of the assets earmarked for privatization, and improved the information backing for the privatization process by distributing information on forthcoming biddings through various channels, including official websites, and by making available more detailed information on each of the assets to be privatized in advance, in the phase of their market valuation and preparatory procedures.

Some potential for further improvement of the privatization process was also created by the alterations that were introduced last year into the privatization law. These alterations differ from those introduced over the period 2010-2011 in that they have nothing to do with the fundamental principles of privatization. Instead, they were aimed at improving the mechanisms applied in sales at auctions, tenders, and sales by means of a public offer, making it possible to shorten the organization procedures and to speed up the sale of assets earmarked for privatization, to shorten the period of holding the down payments of the participants in a bidding, and to lower the potential risk of conspiracy between them, thus ensuring an adequately competitive environment $^{2}$. One important component of all these innovations is the mecha-

1 www.economy.gov.ru, April 1, 2016.

2 Malginov G., Radygin A. Innovations in Russian privatization legislation: cosmetic measures or acceleration of de-nationalization? Russian Economic Developments, 2016, No 2, pp. 91-98. 
nism of an electronic sale of state and municipal property. On the basis of recent amendments to the privatization law, the RF Government drew up, in December 2015, the list of 6 legal entities to be assigned the task of conducting electronic property sales.

Rosimushchestvo's efforts aimed at improving the overall performance, increasing the transparency of privatization procedures, and ensuring the availability of relevant information, were combined with increased control over the financial and economic status of the JSCs earmarked for privatization and better protection of their assets, in order to ensure their attractiveness for investors in the pre-privatization period (the issuance of a special set of instructions (directives) for their boards of directors and recommendations for the audit commissions concerning quarterly monitoring of their financial and economic activity, and the introduction of special provisions into their charters whereby the powers granted to the CEOs of those companies with regard to disposal of their property were to be restricted, and their personal responsibility for the decision-making process to be increased).

Due to the more careful pre-sale preparation and marketing of the assets earmarked for privatization, in spite of the plummeting volume of sales of shares (or stakes in the charter capital) in response to the deteriorating economic situation and declining investment activity, it was still possible to generate some additional privatization revenues.

Compared to the year-end results of the crisis year 2009 (when stakes in 52 economic societies were sold to the value of $\mathrm{Rb} 1.37 \mathrm{bn}$ ), we may conclude that the privatization process in 2015 was more successful (stakes in 103 economic societies were sold to the value of $\mathrm{Rb} 7.34 \mathrm{bn}$ ). Rosimushchestvo explains this success by the systemic changes in the privatization procedures applied to federal property entities and the implementation of comprehensive measures designed to ensure the pre-sale preparation and proper management of the assets to be privatized. However, in this connection it is necessary to remember that inflation had surged since then nearly 1.5 times, and besides, back in 2009, more than half of the sales involved minority state stake, and that no non-governmental sellers participated in the privatization process.

The purpose of involving non-governmental sellers was that of increasing the number of sales, because it was expected that a seller working for a commission calculated as a percentage of the value of a deal and received from the budget, must necessarily make special efforts to boost the selling price in the course of bidding, and so try to involve as many participants as possible. This goal can indeed be achieved, provided that the independent seller is really competent in marketing and possesses the skills necessary for attracting investors. However, the statistics concerning the operation of non-governmental sellers in 2015 was by no means always indicative of such achievements. The effectiveness index of property sales, measured as cumulative growth of asset value during an auction, was found to be lower for OJSC $R A D$ than for Rosimushchestvo (growth by $11 \%$ vs. $17 \%$ ), in spite of the fact that some relatively liquid assets from among the properties listed in the privatization program were handed over to the non-governmental sellers. ${ }^{1}$ The assessment of their performance in the course of implementing the privati-

12015 Report on the Implementation of the Forecast Plan (Program) of Federal Property Privatization in 2014-2016, www.rosim.ru, February 2, 2016. 
zation program, as compared to the performance of government agencies acting in accordance with the established model procedures, should also take account of the size of commission paid to them.

On the negative side, some of the privatization deals completed last year gave rise to loud scandals, which happened after a lull of nearly two years. While in 2012, scandals were centered around the sales of big property entities accomplished in the framework of individual schemes with the involvement of investment consultants (Vanino Commercial Sea Port OJSC, SG-Trans OJSC), in 2015 they had to do with medium-sized companies sold in accordance with the established model procedures.

The most notorious one was the cancellation of bidding for the $100 \%$ state stake in the Training \& Testing Dairy Plant (UOMZ) under N.V. Vereshchagin Vologda State Dairy Academy (Vologda Butter ${ }^{\mathrm{TM}}$ ). The situation that had evolved around the sale of UOMZ put to light many problematic aspects of Russia's privatization process: the feasibility of selling one or other asset currently held by the State, its objective valuation, transparency, and coordination of the interests of the parties in a deal. In this particular case, it was the regional authority who, with public support, opposed the privatization deal. Their arguments were as follows: that the enterprise was profitable; that is was implementing an investment program; that its privatization might entail rising unemployment and production reorientation, loss of the traditional product recipes and its unique brand; and the loss of a base for training qualified personnel. After the sale had been canceled twice, the federal authorities declared that investment consultants would be specifically selected in order to determine the key conditions and elaborate the structure of a potential deal, so as to attract strategic Russian investors and enforce the terms whereby no production reorientation might be attempted ${ }^{1}$.

Problems also arose in connection with some other deals handled by OJSC RAD, due in the main to the resistance of regional authorities: the sale of Murmansk Sea Fishing Port (the biggest deal, according to the year-end results of 2015) and SIC Supermetal JSC, the privatization of the latter having been previously suspended by Rosimushchestvo (more than 40 state stakes were suspended out of a total of 204 transferred to RAD OJSC for sale); the dates of sales of the Saratov Polygraphic Combine and Sverdlovskavtodor were set for Q1 $2016^{2}$.

In spite of the evidently negative effects of the current macroeconomic situation and the recent developments in the stock market, Rosimushchestvo was still able, in the course of implementing the Forecast Plan, to achieve the annual privatization-generated revenue target in the federal budget as early as November 2015 ( $\mathrm{Rb}$ 5bn, less biggest property sales). However, the total value of sales of shares declined in 2015 on 2014 by $8.5 \%$ (Rb 7.34bn vs. Rb $8.02 \mathrm{bn})$.

In 2015, the aggregate federal budget revenue generated by privatization (or sale) and use of state property increased on the previous year by less than $8 \%$ (Table 1). Its amount in absolute terms ( $\mathrm{Rb} 304.3 \mathrm{bn}$ ) comes second after the record high of the entire period since the early 2000s, achieved in 2012 (although the latter figure takes no account of the proceeds received by the RF Central Bank as a result of sale of shares in Sberbank).

1 www.rosim.ru, February 12, 2016.

2 Pushkarskaia A., Butrin D. Rosimushchestvo lacks courage. Kommersant, January 14, 2016. 
Table 1

THE STRUCTURE OF PROPERTY-GENERATED FEDERAL BUDGET REVENUES FROM MISCELLANEOUS SOURCES, 2000-2015

\begin{tabular}{|c|c|c|c|c|c|c|}
\hline \multirow[t]{2}{*}{ Year } & \multicolumn{2}{|c|}{$\begin{array}{l}\text { Aggregate revenue } \\
\text { generated by privatiza- } \\
\text { tion (or sale) and use } \\
\text { of state property }\end{array}$} & \multicolumn{2}{|c|}{$\begin{array}{l}\text { Privatization-generated } \\
\text { revenues (non- } \\
\text { renewable sources) }\end{array}$} & \multicolumn{2}{|c|}{$\begin{array}{l}\text { Revenues generated by } \\
\text { use of state property } \\
\text { (renewable sources) }\end{array}$} \\
\hline & $\mathrm{m} \mathrm{Rb}$ & $\%$ of total & $\mathrm{m} \mathrm{Rb}$ & $\%$ of total & $\mathrm{m} \mathrm{Rb}$ & $\%$ of total \\
\hline 2000 & $50,412.3$ & 100.0 & $27,167.8$ & 53.9 & $23,244.5$ & 46.1 \\
\hline 2001 & $39,549.8$ & 100.0 & $10,307.9$ & 26.1 & $29,241.9$ & 73.9 \\
\hline 2002 & $46,811.3$ & 100.0 & $10,448.9$ & 22.3 & $36,362.4$ & 77.7 \\
\hline 2003 & $135,338.7$ & 100.0 & $94,077.6$ & 69.5 & $41,261.1$ & 30.5 \\
\hline 2004 & $120,798.0$ & 100.0 & $70,548.1$ & 58.4 & $50,249.9$ & 41.6 \\
\hline 2005 & $97,357.4$ & 100.0 & $41,254.2$ & 42.4 & $56,103.2$ & 57.6 \\
\hline 2006 & $93,899.8$ & 100.0 & $24,726.4$ & 26.3 & $69,173.4$ & 73.7 \\
\hline 2007 & $105,761.25$ & 100.0 & $25,429.4$ & 24.0 & $80,331.85$ & 76.0 \\
\hline 2008 & $88,661.7$ & 100.0 & $12,395.0$ & 14.0 & $76,266.7$ & 86.0 \\
\hline 2009 & $36,393.7$ & 100.0 & $4,544.1$ & 12.5 & $31,849.6$ & 87.5 \\
\hline 2010 & $88,406.4$ & 100.0 & $18,677.6$ & 21.1 & $69,728.8$ & 78.9 \\
\hline 2011 & $240,964.1$ & 100.0 & $136,660.1$ & 56.7 & $104,304.0$ & 43.3 \\
\hline 2012 & $\begin{array}{l}309,943.2 / \\
469,243.2^{*}\end{array}$ & 100.0 & $\begin{array}{c}80,978.7 / \\
240,278.7^{*}\end{array}$ & $\begin{array}{l}26.1 / \\
51.2^{*}\end{array}$ & $228,964.5$ & $\begin{array}{l}73.9 / \\
48.8^{*}\end{array}$ \\
\hline 2013 & $209,114.85$ & 100.0 & $55,288.6$ & 26.4 & $153,826.25$ & 73.6 \\
\hline 2014 & $282,325.95$ & 100.0 & $41,155.35$ & 14.6 & $241,170.6$ & 85.4 \\
\hline 2015 & $304,263.7$ & 100.0 & $19,792.4$ & 6.5 & $284,471.3$ & 93.5 \\
\hline
\end{tabular}

* including the proceeds received by the RF Central Bank as a result of sale of a stake in Sberbank ( $\mathrm{Rb} 159.3 \mathrm{bn}$ ), which is probably an overestimation of the actual aggregate share of non-renewable sources, as the budget did not receive that sum in full but minus the balance sheet value of those sources and the costs of the sale of that stake. Consequently, the share of renewable sources is, on the contrary, somewhat underestimated

Source: Laws on Federal Budget Execution for the period 2000-2014; Report on Federal Budget Execution as of January 1, 2016 (monthly report), www.roskazna.ru; own calculations.

In this connection, the relative share of non-renewable sources in the structure of aggregate revenues generated by privatization (or sale) and use of state property shrank more than twofold - to $6.5 \%$, thus hitting its record low of the entire period since the early 2000s. The share of revenues generated by the use of state property, on the contrary, increased from nearly $85.4 \%$ to $93.5 \%$ in 2015.

In 2015, Rosimushchestvo established 18 vertically integrated structures (VIS), of which all the necessary formalities had been completed for 10. Among the new decisions in this direction issued in late 2015 and Q1 2016, we should note the enlargement of major national holding companies of strategic importance: United Aircraft Corporation (UAC) JSC (by contributing to its charter capital the stakes in $4 \mathrm{JSCs}$, including a controlling stake (62.8\%) in RAC MiG (Russian Aircraft Corporation) and minority stakes in another 3 JSCs); and Tactical Missiles Corporation (TMC) JSC (by contributing to its charter capital the stakes in two JSCs (a blocking stake of 36.9\% and a minority stake of $24.3 \%$ ), to be later contributed to the charter capital of Concern Sea Underwater Weapons - Gidropribor JSC, whose federal stake is also earmarked as a contribution to the charter capital of Tactical Missiles Corporation JSK).

The outcome of the current privatization program, to be completed this year, will be determined by the situation in the Russian economy in general, 
and by the behavior of the domestic stock market in particular. In the explanatory documents attached to the draft law on federal budget for 2016 submitted to parliament by the government, it is stated that the revenues from privatization are expected to amount to more than $\mathrm{Rb} 33.2 \mathrm{bn}$, including $\mathrm{Rb}$ $12 \mathrm{bn}$ (or $36 \%$ ) expected to be generated by the sale of a stake in Sovkomflot PJSC $^{1}$. These figures do not appear to be quite realistic. In fact, the budget revenue target of $\mathrm{Rb} 21.2 \mathrm{bn}$, to be generated by privatization in 2016 (less revenues generated by biggest deals), is comparable to the corresponding index for the entire 3-year period of the implementation of the privatization program for 2011-2013, when the federal budget had received $\mathrm{Rb} 25.67 \mathrm{bn}$. However, that result was achieved within the framework of an economic and political situation that was radically different from what we have been experiencing over the course of two recent years (large-scale capital outflow, the introduction of economic sanctions, the ruble's plummeting exchange rate, and the probability of recession in the national economy). Besides, the proceeds generated by biggest deals clearly accounted for the bulk of all privatization revenue.

In Q1 2016, according to information released by Rosimushchestvo, 32 stakes were sold to the total value of $\mathrm{Rb} 1,790.35 \mathrm{~m}$, of which about $88 \%$ was generated by RAD OJSC (which sold 12 stakes; although more than half of all stakes were sold by Rosimushchestvo's territorial agencies ${ }^{2}$. According to the monthly report on federal budget execution as of April 1, 2015 (data on the sources of funding to cover federal budget deficit) posted to the Federal Treasury's official website, the total revenues generated by sale of federal stakes or other forms of participation in charter capital amounted to Rb 2,093.1m.

The evident difficulties experienced by the budgetary system prompted the decisions concerning the expansion of the privatization program in early 2016. The candidates for the privatization of part of their state stakes were Alrosa, Bashneft, VTB, Rosneft, Sovkomflot and some other companies; however, the prospects for and format of each of these deals are still unclear.

All the preparations for the alienation of shares in Sovkomflot PJSC (which was postponed in 2015) have been completed, and the deal is ready to be launched. As for Rosneft, the major obstacle is the current situation in the stock market - its stock quotes are now below the alienation threshold value established in 2014 (the price of primary public offer in 2006.), and so an alienation deal can be attempted only after they climb back above the threshold.

The reduction to $45 \%$, in February 2016, of the state stake in VTB Bank PJSC (Public Corporation) was caused by the necessity to make it compatible with the permitted size of state stake (as envisaged in the List of Strategic Organizations, to which VTB Bank belongs), because it had increased after the completion of the purchase, by State Corporation Deposit Insurance Agency (DIA), of a big chunk of preference shares in VTB, while the State retained its right of corporate control through its bundle of voting shares. As

1 In this connection it should be noted that Federal Law on the Federal Budget for 2016 (No 359-FZ), adopted as of 14 December 2015, contains no specific information as to the amount of revenue to be generated by sale of federal stakes or other forms of participation in charter capital, and does not specify such deals as an independent source of funding to cover federal budget deficit,

2 www.rosim.ru, April 7, 2016. 
for the other two companies named among the candidates for privatization (Alrosa and Bashneft), these are noteworthy for their involvement in the relations between the federal center and the regions, which by now have been formalized by special provisions introduced into their shareholders agreements, concluded in 2013 and 2015 respectively. As of early April 2016, the RF Ministry of Economic Development had selected the legal entities that will be assigned the task of organizing the sale of stakes in these 3 companies on behalf of the State (Alrosa, Bashneft and VTB) ${ }^{1}$.

The mandatory requirements for conducting the deals of sale of public assets, as they were put forth by this country's political leaders, will make it very difficult to proceed with privatization in the foreseeable future. These are as follows: (1) strict compliance with the norms stipulated in legislation when completing privatization deals, (2) retaining government corporate control over system-forming companies, (3) budget efficiency and avoidance of asset sale at throwaway prices, (4) topmost priority should be given to 'quality owners' who must possess not only a good business reputation and experience, but offer a development strategy for the company being purchased, (5) the new owners must be subject to Russian jurisdiction, there should be no 'gray schemes' or withdrawal of assets to offshore zones and concealment of their real owners, (6) the use, by buyers, only of their own means or loans issued by private banks

Considering all these circumstances, it is evident that the final phase in the implementation of the privatization program for 2014-2016 will be very difficult, in view of the controversial macroeconomic situation, low investment activity, and the economic sanctions introduced against Russia's major companies. At the same time, it should be borne in mind that the numerous objective constraints are still in place, and that they will hinder the successful completion of all the privatization measures planned for 2014-2016:

- it will be impossible to privatize approximately half of all the stakes held by the RF in non-strategic joint-stock companies of the following types: those with state stakes less than $2 \%$; those where the shareholder rights on behalf of the Russian Federation are exercised by other federal bodies of executive authority or state corporations; those undergoing bankruptcy procedures (in the phase of a bankruptcy proceeding); those undergoing a liquidation procedure, etc.;

- there is no interdepartmental coordination of decision-making, and first of all of the decisions concerning the privatization deals involving unitary enterprisers; besides, the existence of this organizational-legal form in Russian legislation per se has given rise to a number of chronic problems;

- there is no synchronization between the decisions concerning the target function of each property entity ('to sell it - or to keep it in RF ownership') and the privatization decisions taken in the framework of the privatization program;

- there is an inherent conflict between the gradual reduction in the number of property entities in RF ownership (JSCs, FSUEs) and the 'privatization potential' of the remaining ones (they are increasingly less attractive due to their low quality, low liquidity, unmanageability, etc.);

1 www.economy.gov.ru, April 4, 2016. 
- there are no properly functioning channels for large-scale sales of treasury-owned property entities (other than blocks of shares) due to the existence of numerous problems (cumbersome technical and registration procedures, low quality of the available assets, absence of the procedure of 'sale for one ruble', lack of proper regulation of the issue of the payment of an adequate commission to an independent seller, etc.).

Evidently, it will be worthwhile, as early as 2016, to make a comprehensive inventory of the existing 'problem zones' and 'difficult' property entities (given that the process of assigning the individual target function to each JSC and FSUE is almost complete). On this basis, the targets of the program for 2014-2016 may be revised, and the possibility of the launch of a new privatization program a year earlier (for 2016-2018) cannot be ruled out, either; or, the existing program can be extended untill the end of the year 2017. 